\title{
Исследование частоты распределения аллелей и генотипов гена CYP2C9 у больных ишемической болезнью сердца, которым показано кардиохирургическое лечение
}

\author{
Морозова Т. Е. ${ }^{1}$, Шацкий Д. А. ${ }^{1}$, Ших Е. В. ${ }^{1}$, Качанова А. А. ${ }^{2}$, Созаева Ж. А. ${ }^{2}$, Сычёв Д. А. ${ }^{2}$ \\ 1 - ФГАОУ ВО «Первый МГМУ им. И.М. Сеченова Минздрава России [Сеченовский Университет]», \\ Россия, Москва \\ 2 - ФГБОУ ДПО «Российская медицинская академия непрерывного профессионального образования» \\ МЗ РФ, Россия, Москва
}

Ключевые слова: СУР2С9; ишемическая болезнь сердца; кардиохирургическое лечение; генотипирование

Для цитирования:

Морозова Т.Е., Шацкий Д.А., Ших Е.В., Качанова А.А., Созаева Ж.А., Сычёв Д.А. Исследование частоты распределения аллелей и генотипов гена СYР2С9 у больных ишемической болезнью сердца, которым показано кардиохирургическое лечение // Фармакогенетика и фармакогеномика. 2020;(2):21. (In Russ). DOI: 10.37489/2588$0527-2020-2-21$

Введение. Ишемическая болезнь сердца (ИБС) является одной из ведущих причин по обращаемости пациентов за медицинской помощью среди всех сердечно-сосудистых заболеваний. Заболеваемость ИБС в РФ, по различным данным, составляет не менее 7 млн человек в год. Несмотря на появление ряда терапевтических и малоинвазивных хирургических методик, открытые кардиохирургические вмешательства являются одними из ключевых вариантов лечения у больных с тяжёлыми формами ИБС. Фармакологическое действие нестероидных противовоспалительных препаратов (НПВП), которые применяются в кардиохирургии для послеоперационного обезболивания, зависит от полиморфизма гена СYР2С9, принимающего участие в метаболизме ряда НПВП. Полиморфные варианты СҮР2С9*2 и СҮР2С9*3 вероятно обуславливают различия в эффективности НПВП у больных с ИБС после кардиохирургических вмешательств, что может играть существенную роль в методах персонализации послеоперационного обезболивания.

Цель: определить частоту встречаемости полиморфных вариантов гена СYР2C9 (CYP2C9*2 и CYР2C9*3) у больных ишемической болезнью сердца в послеоперационном периоде после кардиохирургических вмешательств.

Материалы и методы. В исследовании приняли участие 90 пациентов, среди которых было 69 (76,6\%) мужчин и $21(23,3 \%)$ женщина в возрасте от 37 до 87

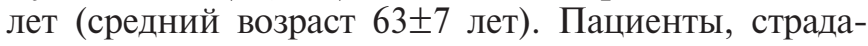
ющие ишемической болезнью сердца, включались в исследование после кардиохирургических вмешательств, сопровождающихся стернотомией: аортокоронарного шунтирования, маммарокоронарного шунтирования, протезирования клапанов, протезирования восходящего отдела аорты. Для послеоперационного обезболивания вводился кетопрофен в дозе
200 мг в сутки в течение не менее 5 дней в соответствии с инструкцией по медицинскому применению. Генотипирование полиморфных вариантов СРР2С9 проводилось с помощью метода полимеразной цепной реакции в режиме реального времени (Real-time PCR). Соответствие независимому распределению аллелей по закону Харди-Вайнберга проверялось с использованием критерия Хи-квадрат Пирсона.

Результаты. Полученные данные генотипирования продемонстрировали следующие результаты: пациенты являлись носителями генотипа СРР2C9*2 430 СС в $85,6 \%$ случаев, СYР2С $9 * 2430$ СТ - в $14,4 \%$ случаев. По полиморфному маркеру СҮР2C9*3 также оказалось выявлено 85,6 \% гомозигот и 14,4 \% гетерозигот. Больных с генотипами СYР2C9*2 430ТT и СҮР2С9*3 1075СС выявлено не было. Распределение генотипов представлено в таблице 1.

Распределение генотипов СУР2C9

Таблииа 1 у больных ишемической болезнью сердца

\begin{tabular}{|l|l|c|}
\hline \multicolumn{2}{|l|}{ Аллель } & Количество $\boldsymbol{n}(\%)$ \\
\hline $\begin{array}{l}C Y P 2 C 9 * 2 \\
(430 C<T) \\
r s 1799853\end{array}$ & Дикий тип СС & $77(85,6 \%)$ \\
\cline { 2 - 3 } $\begin{array}{l}C Y P 2 C 9 * 3 \\
(1075 A<C)\end{array}$ & Дутантный аллель СТ & $13(14,4 \%)$ \\
\cline { 2 - 3 } rs 1057910 & Мутантный тип АА & $77(85,6 \%)$ \\
\hline
\end{tabular}

Распределения генотипов СҮР2C9*2 и СYР2C9*3 не отклонялись от равновесия Харди-Вайнберга ( $\chi^{2}=0,60 ; p=0,43$ и $\chi^{2}=0,60 ; p=0,43$, соответственно).

Заключение. Изучено распределение генотипов полиморфизмов СҮР2С9*2 и СҮР2С9*3 у больных ишемической болезнью сердца. Отклонений от равновесия Харди-Вайнберга не обнаружено.

Работа выполнена при финансовой поддержке Гранта Президента РФ для научных школ № НШ-2698.2020.7. 